\title{
Protein Synthesis in Brucella abortus Induced during Macrophage Infection
}

\author{
JYHSHIUN LIN† AND THOMAS A. FICHT* \\ Department of Veterinary Pathobiology, College of Veterinary Medicine, Texas A\&M University \\ and Texas Agricultural Experiment Station, College Station, Texas 77843-4467
}

Received 16 March 1994/Returned for modification 25 May 1994/Accepted 13 January 1995

\begin{abstract}
Brucella abortus is a facultative, intracellular, pathogenic bacterium that replicates within macrophages and resists macrophage microbicidal mechanisms. To study gene expression and to elucidate the defense mechanisms used by $B$. abortus to resist destruction within macrophages, protein synthesis by $B$. abortus was examined by pulse-labeling techniques during intracellular growth within J774A.1, a macrophage-like cell line. Prominent changes observed include increased synthesis of Brucella proteins with estimated molecular masses of 62, 28, 24, and $17 \mathrm{kDa}$. The 62-kDa protein was identified by immunoprecipitation analysis as Hsp62, a GroEL homolog. A protein of $60 \mathrm{kDa}$ was expressed during acid shock and may represent a modified form of Hsp62. The 28- and 17-kDa proteins have not been observed under any in vitro stress condition and presumably represent macrophage-specific induction. The $24-\mathrm{kDa}$ protein comigrates with an unidentified protein induced by acid shock, designated Asp24. Expression of Asp24 is optimal at pH values below 4.0 and within the first $3 \mathrm{~h}$ following a shift from $\mathrm{pH} 7.3$ to 3.8. This corresponds directly with a period of optimal bacterial survival at a reduced $\mathrm{pH}$ and suggests an active role for this protein in resistance to such environments. The identification of these gene products and the mechanisms controlling their expression is an important step in understanding the resistance of Brucella spp. to intracellular destruction within macrophages.
\end{abstract}

Brucella abortus is a gram-negative, facultative, intracellular bacterium. In cattle, brucellosis is characterized by the initial replication of Brucella organisms in the lymph nodes of the oral pharynx, after which the organisms eventually localize in the primary target tissue, the reproductive organs, udder, and supra-mammary-gland lymph nodes $(33,35)$. The establishment of chronic infections depends on the ability of the brucellae to survive within phagocytic cells $(19,37)$. Evidence also indicates that $B$. abortus localizes in phagosomes and phagolysosomes of macrophages following phagocytosis (19). Evidence from $B$. abortus infection of Vero cells suggests that phagosomal acidification is required to transfer B. abortus from phagosomes to the rough endoplasmic reticulum, where replication occurs (12).

Although there is no evidence that $B$. abortus can access the rough endoplasmic reticulum of the macrophage, organisms have been shown to replicate inside macrophages (23). The intracellular environment of the phagocytic cell is inhospitable for most bacteria. Following phagocytosis, bacteria generally confront at least two different environments: (i) the phagosome, a pH 5 to 6 environment; and (ii) the phagolysosome, characterized by an internal $\mathrm{pH}$ of 4.5 to 5 , oxidative free radicals, and lysosomal enzymes. Clearly, the ability to withstand acidic environments is an important factor in the virulence of intracellular bacteria. Salmonella typhimurium and Legionella pneumophila have adapted to the intracellular environment of macrophages by altering protein synthesis from multiple regulons $(1,7)$.

While little is known about the gene products required for survival, growth, and pathogenesis of B. abortus in the intracellular environment of phagocytic cells, evidence from other bacterial systems indicates that expression of virulence genes is coordinately regulated in response to environmental changes

\footnotetext{
* Corresponding author. Phone: (409) 845-4118. Electronic mail address: TFICHT@VETMED.TAMU.EDU.

$\dagger$ Present address: Swine Research Institute, Chunan 35099, Miaoli, Taiwan.
}

(30). This includes genes responsive to changes in the $\mathrm{pH}$ of the environment. Activation of bacterial gene expression by phagosomal acidification has been demonstrated for $S$. typhimurium and is regulated by the PhoP-PhoQ two-component system (3). PhoQ is a transmembrane sensor which recognizes environmental changes, including changes in the external $\mathrm{pH}$, and phosphorylates PhoP. The activated form of PhoP in turn induces transcription from the PhoP-activated genes (pagC, $\operatorname{pag} B$, and $\operatorname{pag} A$ ), which are essential for survival within macrophages (31). The activities of VirA and VirG, a related system of Agrobacterium spp., are also controlled by external $\mathrm{pH}(30)$.

The purpose of the study reported here was to characterize the synthesis of proteins by $B$. abortus in response to the intracellular environment of macrophages by using gel-electrophoretic analysis. This study revealed that, as with other bacterial pathogens, various stress conditions (e.g., phagocytosis and acid shock) alter the synthesis of proteins in B. abortus. Although there appears to be some overlap between each of these responses and heat shock, the synthesis of several proteins is unique to each condition. These stress-induced proteins may be related to resistance to the bactericidal activity of macrophages and to the pathogenicity of B. abortus.

(This work was conducted in partial fulfillment of the requirements for the Ph.D. degree by J. Lin, Texas A\&M University. Portions of this work were presented at the 93rd General Meeting of the American Society for Microbiology, Atlanta, Ga., 1993.)

\section{MATERIALS AND METHODS}

Bacterial strains. B. abortus smooth strains 19 and 2308 (S19 and S2308) and rough strain RB51 were obtained from Billy Deyoe at the National Animal Disease Center in Ames, Iowa. All strains were confirmed by standard biotyping procedures, maintained as glycerol stocks at $-80^{\circ} \mathrm{C}$, and grown to confluency on tryptic soy agar (TSA; Difco Laboratories) plates for 48 to $72 \mathrm{~h}$ at $37^{\circ} \mathrm{C}$ with $5 \%$ $\mathrm{CO}_{2}(2)$.

Radiolabeling of Brucella proteins in organisms exposed to macrophages. The following experiments were performed as described by Buchmeier and Heffron 
with some modifications (7). To determine whether expression of certain proteins was induced intracellularly, Brucella proteins synthesized after infection of macrophages were compared with those synthesized under identical culture conditions in the absence of macrophages. J774A.1 macrophages $\left(10^{5}\right)$ in RPMI 1640 containing $5 \%$ (vol/vol) heat-inactivated calf serum (GIBCO Laboratories) were allowed to adhere to each well of a 24-well plate. Following overnight incubation, the wells were washed with methionine-free RPMI 1640 to remove nonadherent macrophages. B. abortus S2308, S19, and RB51 were grown as described above, pelleted at 3,000 rpm (model TJ-6 centrifuge; Beckman Instruments, Inc.) for $25 \mathrm{~min}$, and resuspended in methionine-free RPMI 1640 to a concentration of $10^{8}$ cells per $\mathrm{ml}$. The macrophages were infected in a final volume of $0.5 \mathrm{ml}$ of methionine-free RPMI 1640 at a ratio of 50 bacteria per macrophage. The plate was then centrifuged at $1,000 \mathrm{rpm}$ for 5 to $10 \mathrm{~min}$ at room temperature to enhance and synchronize infection and incubated for $40 \mathrm{~min}$ to permit phagocytosis. Free bacteria were then removed by using three washes with methionine-free RPMI 1640, and $0.2 \mathrm{ml}$ of methionine-free RPMI 1640 containing $50 \mu \mathrm{g}$ of cycloheximide and $20 \mu \mathrm{g}$ of gentamicin per ml was added to each well. Following a 1-h incubation, proteins were labeled for $2 \mathrm{~h}$ with $50 \mu \mathrm{Ci}$ of $\left[{ }^{35} \mathrm{~S}\right]$ methionine per $\mathrm{ml}$. The medium was aspirated, and the infected cells adhering to the plastic were washed three times with $1 \mathrm{ml}$ of phosphate-buffered saline (PBS; $145 \mathrm{mM} \mathrm{NaCl}, 49 \mathrm{mM} \mathrm{KH}_{2} \mathrm{PO}_{4}$, and $21 \mathrm{mM} \mathrm{Na}_{2} \mathrm{HPO}_{4} ; \mathrm{pH} 7.2$ ). The macrophages were lysed with $200 \mu \mathrm{l}$ of sterile normal saline containing $0.1 \%$ (wt/vol) deoxycholate, $100 \mu \mathrm{g}$ of phenylmethylsulfonyl fluoride per $\mathrm{ml}$, and 100 mM EDTA. The bacteria were heat killed in $500 \mu \mathrm{l}$ of phenol-saline $(150 \mathrm{mM}$ $\mathrm{NaCl}, 0.5 \%$ [wt/vol] phenol) for $1 \mathrm{~h}$ at $65^{\circ} \mathrm{C}$ and mixed with 5 volumes of acetone, which lyses the bacteria and precipitates total cellular proteins. The cell pellet was resuspended in $100 \mu \mathrm{l}$ of PBS $(\mathrm{pH} \mathrm{7.2)}$. Three 2.0- $\mu$ l portions of each reaction mixture were precipitated with $10 \%$ (wt/vol) trichloroacetic acid and collected onto glass fiber filters, which were washed several times with $5 \%$ (wt/vol) trichloroacetic acid and dried under a heat lamp. $\left[{ }^{35}\right.$ S]methionine incorporation was measured in a Beckman LS 3133 T model (Beckman Instruments, Inc.) liquid scintillation counter. Samples were prepared for electrophoresis by the addition of Laemmli sample buffer as described elsewhere (28). Equal numbers of counts per minute were applied to all lanes.

To compare the profile of protein synthesis of opsonized and nonopsonized organisms during the infection of macrophages, $10^{8}$ cells of $B$. abortus S2308 were treated for $30 \mathrm{~min}$ at room temperature in $1 \mathrm{ml}$ of methionine-free RPMI 1640 containing (i) no supplements, (ii) a 1:100 dilution of heat-inactivated mouse anti-S19 serum, (iii) a 1:100 dilution of mouse complement (Sigma Chemical Co.; measured in $50 \%$ hemolytic complement units per milliliter), or (iv) both the mouse anti-S19 serum and the mouse complement. The opsonized and nonopsonized organisms were then used to infect macrophages and were radiolabeled with $\left[{ }^{35} \mathrm{~S}\right]$ methionine as described above. Samples were prepared for electrophoresis as previously described (28), and in all cases equal numbers of counts per minute $\left(0.5 \times 10^{5}\right.$ to $\left.1.0 \times 10^{5} \mathrm{cpm}\right)$ were applied to the gels.

Radiolabeling of Brucella proteins in organisms cultured at reduced $\mathbf{p H}$. $B$. abortus S2308, S19, and RB51 were grown to mid-log phase (50 to $100 \mathrm{Klett}$ units) in tryptic soy broth (Difco Laboratories) at $37^{\circ} \mathrm{C}$ with $5 \% \mathrm{CO}_{2}$. The cells were pelleted at 8,000 rpm (J-20 rotor; Beckman Instruments, Inc.) for $15 \mathrm{~min}$ and resuspended to $10^{8} \mathrm{CFU} / \mathrm{ml}$ in methionine-free RPMI 1640. The cell suspension $(1 \mathrm{ml})$ was then pulse-labeled for $1 \mathrm{~h}$ with $50 \mu \mathrm{Ci}$ of $\left[{ }^{35} \mathrm{~S}\right]$ methionine per $\mathrm{ml}$ at hourly intervals up to $6 \mathrm{~h}$ following the $\mathrm{pH}$ shift from 7.3 to 3.8 or for 45 min in acidified culture media previously adjusted to $\mathrm{pH} 3.8,4.5,5.5,6.5$, or 7.3 with $1 \mathrm{~N} \mathrm{HCl}$ following a 15-min pretreatment. After incubation, the cells were washed twice with PBS and pelleted at $8,000 \mathrm{rpm}$ for $15 \mathrm{~min}$. The bacteria were heat killed and prepared for electrophoresis as described above.

To measure the survival rate of brucellae following the shift from $\mathrm{pH} 7.3$ to $\mathrm{pH}$ $3.8,100-\mu l$ portions were withdrawn from each culture, serially diluted into PBS, and spread on the surface of TSA plates to determine the number of viable cells at intervals of up to $24 \mathrm{~h}$ following the $\mathrm{pH}$ shift. CFU were counted following 72 $\mathrm{h}$ of incubation on TSA plates at $37^{\circ} \mathrm{C}$ in an atmosphere containing $5 \%$ (vol/vol) $\mathrm{CO}_{2}$.

One- and two-dimensional PAGE analysis of proteins. Two-dimensional polyacrylamide gel electrophoresis (PAGE) was performed as described by O'Farrell (34). Isoelectric focusing (IEF) gels were cast in capillary tubes (Bio-Rad Laboratories). The IEF gel mixture was prepared according to the manufacturer's (Bio-Rad Laboratories) recommendations. Equal numbers of counts per minute of $\left[{ }^{35} \mathrm{~S}\right]$ methionine-labeled Brucella proteins were loaded onto the lanes of the IEF gels, which were run at $500 \mathrm{~V}$ for $15 \mathrm{~min}$ and then adjusted to $750 \mathrm{~V}$ for another $3 \mathrm{~h}$. The tube gels were equilibrated with sodium dodecyl sulfate (SDS) sample equilibration buffer made as recommended by Bio-Rad Laboratories and loaded onto the second-dimension gel (SDS-12\% PAGE). The gels were dried at $80^{\circ} \mathrm{C}$ under vacuum. The labeled proteins were visualized by exposing the dried gel to X-ray film (Kodak XAR-5) for up to 1 week.

Immunoprecipitation of $\left[{ }^{35} \mathrm{~S}\right]$ methionine-labeled polypeptides with anti- $B$. abortus Hsp62 rabbit serum. Samples containing equal numbers of counts of labeled Brucella proteins were used in immunoprecipitation analysis with antiHsp62 rabbit serum raised against the Brucella protein as described in a previous report (28). Electrophoresis was performed as described above.

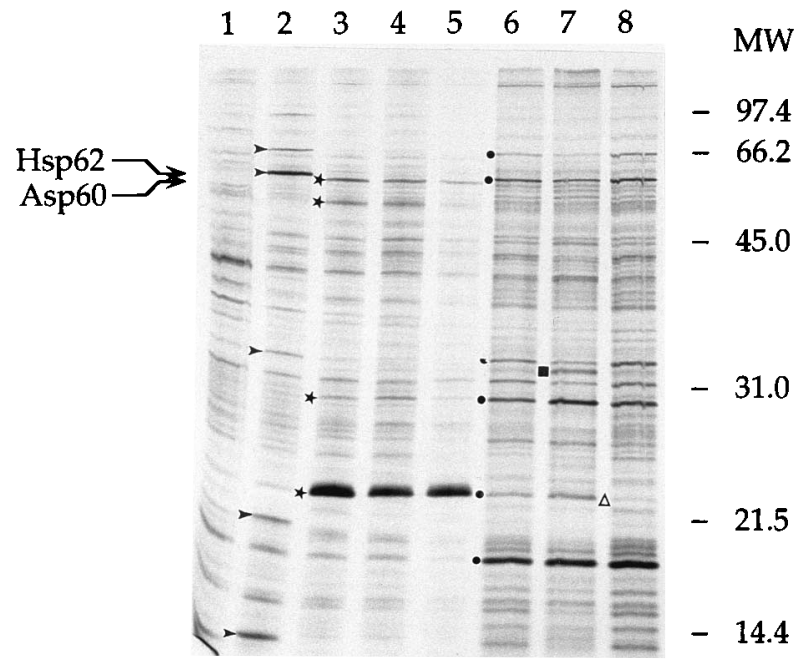

FIG. 1. Stress-induced modifications of protein synthesis in B. abortus. Bacterial cells (B. abortus S2308 [lanes 1 to 3 and 6], B. abortus S19 [lanes 4 and 7], and $B$. abortus RB51 [lanes 5 and 8]) were grown as described in Materials and Methods and radiolabeled after being exposed to $37^{\circ} \mathrm{C}$ (lane 1 ), $44^{\circ} \mathrm{C}$ (lane 2), or pH 3.8 (lanes 3 to 5) or after being engulfed by macrophages (lanes 6 to 8 ). Total cellular protein was extracted, and equal numbers of counts $\left(5 \times 10^{4} \mathrm{cpm}\right)$ were loaded in all lanes. Proteins were separated by SDS-PAGE followed by autoradiography. $\boldsymbol{>}$, increased protein synthesis under heat shock conditions; $\star$, increased protein synthesis at $\mathrm{pH} 3.8 ; \boldsymbol{Q}$, increased protein synthesis during macrophage infection; $\mathbf{\square}$, increased protein synthesis unique to S19 within infected macrophages; $\triangle$, increased protein synthesis in S2308 and S19 infected macrophages; MW, molecular weight (in thousands).

\section{RESULTS}

SDS-PAGE analysis of $B$. abortus protein synthesis in response to macrophage phagocytosis. In order to characterize protein synthesis in Brucella spp. in response to phagocytosis, brucellae were pulse-labeled with $\left[{ }^{35} \mathrm{~S}\right]$ methionine shortly after engulfment by J774A.1 macrophages. To inhibit extracellular bacterial growth and to minimize macrophage protein synthesis following phagocytosis, gentamicin and cycloheximide were added to the medium $1 \mathrm{~h}$ prior to labeling $(7,9,12)$. Protein labeling was performed during an additional 2-h incubation. One-dimensional SDS-PAGE analysis comparing proteins synthesized under these conditions with those synthesized at $37^{\circ} \mathrm{C}$ in the absence of macrophages revealed large increases in the synthesis of $B$. abortus proteins of 62,28 , and $17 \mathrm{kDa}$ and minor increases in the synthesis of $B$. abortus proteins of 70, 36, 26 , and $24 \mathrm{kDa}$ (Fig. 1, lanes 6 to 8). Little difference was observed among organisms which differed widely in their virulence characteristics (i.e., S19, S2308, and RB51). Additional proteins induced by exposure to macrophages are revealed by two-dimensional gel electrophoresis (unpublished results). These data suggest that brucellae respond to phagocytosis by synthesizing proteins which are not required for growth in media. Although several of the proteins synthesized appear to correspond to heat shock proteins, notably GroEL (62 kDa) and DnaK (70 kDa), the majority of proteins induced following phagocytosis have not been characterized.

Protein synthesis in B. abortus at reduced pH. In a first step towards characterizing the proteins synthesized in Brucella spp. following phagocytosis, brucellae were resuspended in media of reduced $\mathrm{pH}$ to mimic the acidic environment of the phagosome and phagolysosome. Proteins synthesized under these conditions were pulse-labeled following the shift to reduced $\mathrm{pH}$ as described in Materials and Methods. Although several approaches are possible, we have found that RPMI 1640 ti- 


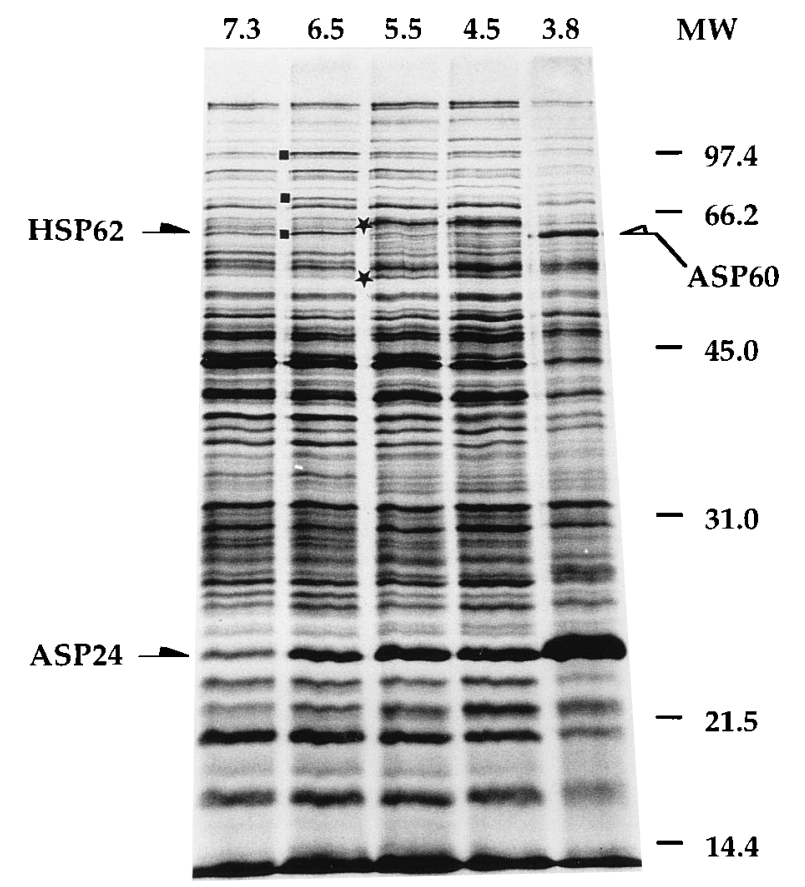

FIG. 2. Protein synthesis in B. abortus as a function of external pH. B. abortus S2308 was exposed to $\mathrm{pH} 7.3,6.5,5.5,4.5$, or 3.8. Bacterial proteins were labeled with $\left[{ }^{35} \mathrm{~S}\right]$ methionine as described in the legend to Fig. 1. Total cellular proteins were extracted, and an equal number of counts $\left(10^{5} \mathrm{cpm}\right)$ was loaded per lane. Proteins were separated by SDS-PAGE followed by autoradiography. $\mathbf{0}$, increased protein synthesis at $\mathrm{pH} 6.5 ; \star$, increased protein synthesis at $\mathrm{pH} 5.5$ and 4.5; MW, molecular weight (in thousands).

trated to the appropriate $\mathrm{pH}$ with hydrochloric acid maintained that $\mathrm{pH}$ during the course of the experiments.

When one-dimensional SDS-PAGE profiles of proteins synthesized in B. abortus incubated at $\mathrm{pH} 3.8$ were compared with those synthesized in $B$. abortus incubated at $\mathrm{pH} 7.3$, major increases in the synthesis of two proteins of $60 \mathrm{kDa}$ (Asp60) and $24 \mathrm{kDa}$ (Asp24) and minor increases in the synthesis of several other proteins were observed in acid-stressed organisms (Fig. 1, lanes 3 to 5). Once again, little difference was observed among organisms which differed in their virulence characteristics (i.e., S19, S2308, and RB51). In order to identify the optimum $\mathrm{pH}$ at which these proteins are expressed, $B$. abortus S2308 proteins were pulse-labeled at several $\mathrm{pH}$ values between 7.3 and 3.8. The results shown in Fig. 2 are from an overexposed autoradiogram which maximizes detection of acid-induced protein synthesis. The $24-\mathrm{kD}$ a protein appearing in the $\mathrm{pH} 7.3$ lane is not related to Asp24 and appears only after prolonged exposure (compare with Fig. 1 and 3). Synthesis of Asp24 was observed to increase steadily with decreasing $\mathrm{pH}$ over the range examined. In contrast, synthesis of Asp60 is apparent only at $\mathrm{pH}$ values of 6.5 and 3.8 (Fig. 2). When the media were adjusted to $\mathrm{pH}$ values of 5.5 and 4.5 , there was no detectable synthesis of Asp60; in its place a prominent protein of $65 \mathrm{kDa}$ was synthesized. It is not clear whether the protein bands observed in the 60 - to $65-\mathrm{kDa}$ range represent related proteins or completely different gene products. Further characterization of these proteins is described below.

Acid shock protein expression and survival at reduced $\mathbf{p H}$. To establish that expression of Asp24 and Asp60 is part of an adaptive response specific to reduced-pH environments, an attempt was made to correlate expression of these proteins with survival of the bacterium. In this experiment, $B$. abortus

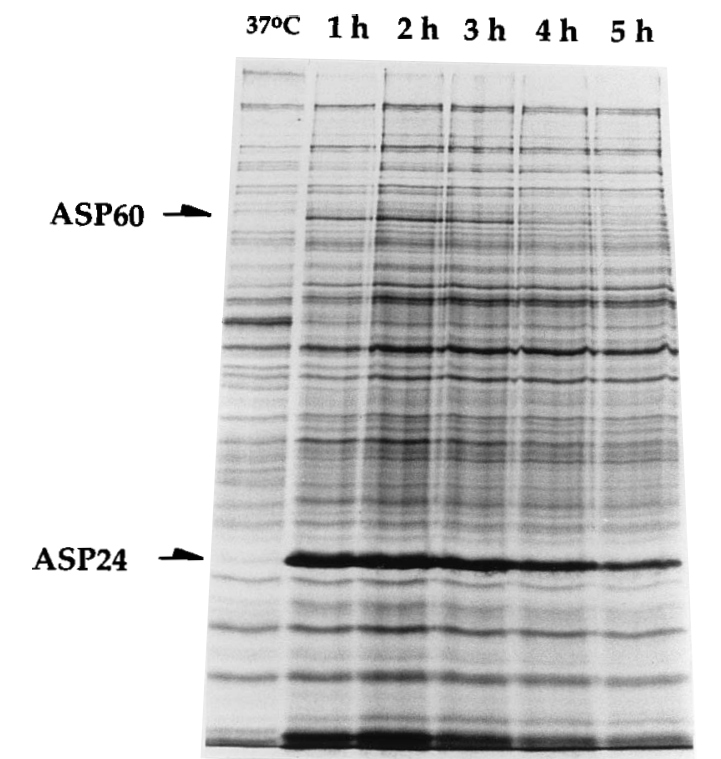

FIG. 3. Duration of acid-induced protein expression in B. abortus. B. abortus S2308 was grown and acid shocked at pH 3.8 as described in Materials and Methods. Proteins were radiolabeled for $1 \mathrm{~h}$ at hourly intervals and separated by SDS-PAGE. Lane $1\left(37^{\circ} \mathrm{C}\right)$, $\mathrm{pH} 7.3$; lanes 2 to $6(1 \mathrm{~h}$ to $5 \mathrm{~h}), \mathrm{pH} 3.8$.

S2308 proteins were pulse-labeled for $1 \mathrm{~h}$ at hourly intervals, up to $5 \mathrm{~h}$, following the $\mathrm{pH}$ shift from 7.3 to 3.8. The expression of both Asp24 and Asp60 was shown to be optimal for $3 \mathrm{~h}$ immediately following the $\mathrm{pH}$ shift (Fig. 3, lanes 2 to 4). This profile was shown to directly coincide with the survival of $B$. abortus $\mathrm{S} 2308$ following the shift from $\mathrm{pH} 7.3$ to $\mathrm{pH} 3.8$ (Fig. 4). Expression of Asp24 occurs during a period in which 85 to $90 \%$ of the brucellae survive; following prolonged exposure, the bacteria gradually die and protein synthesis declines as a result of the reduced internal pH (Fig. 5) (16). Resistance of $B$. abortus to acid pHs may be said to represent a relatively shortlived phenomenon but may nevertheless be sufficient to increase the chances for survival and dissemination within the host.

Characterization of proteins expressed under conditions of acid shock and macrophage infection. Immunoprecipitation analysis of $B$. abortus proteins was performed in an attempt to identify the macrophage- and acid-induced proteins. The 62$\mathrm{kDa}$ protein observed under heat shock conditions and the $60-\mathrm{kDa}$ protein observed under acid conditions were both immunoprecipitated using antibody raised against the Hsp62 protein (Fig. 6); however, the presence of Asp60 in the preparation used to prepare the rabbit antisera cannot be ruled out (28). The protein expressed at a reduced $\mathrm{pH}$ and identified in Fig. 1 as Asp60 migrates more rapidly than Hsp62 in SDSPAGE (Fig. 1 and 7), although this distinction is not always apparent (Fig. 6). The results from two-dimensional gel electrophoresis also confirm the faster migration in the SDSPAGE dimension of the gel (Fig. 7). Multiple forms with various isoelectric points are also apparent in the IEF dimension and are similar to the forms observed with Hsp62, albeit slightly more basic. Additional experiments are necessary to confirm the identity of this gene product and to determine whether Asp60 represents an unrelated protein, the product of a related gene $(18,24,26,38)$, or a modified version (posttranslational modification) of Hsp62 (11, 29, 41).

Effect of opsonization on macrophage-induced protein synthesis. Macrophages possess several molecules on their sur- 


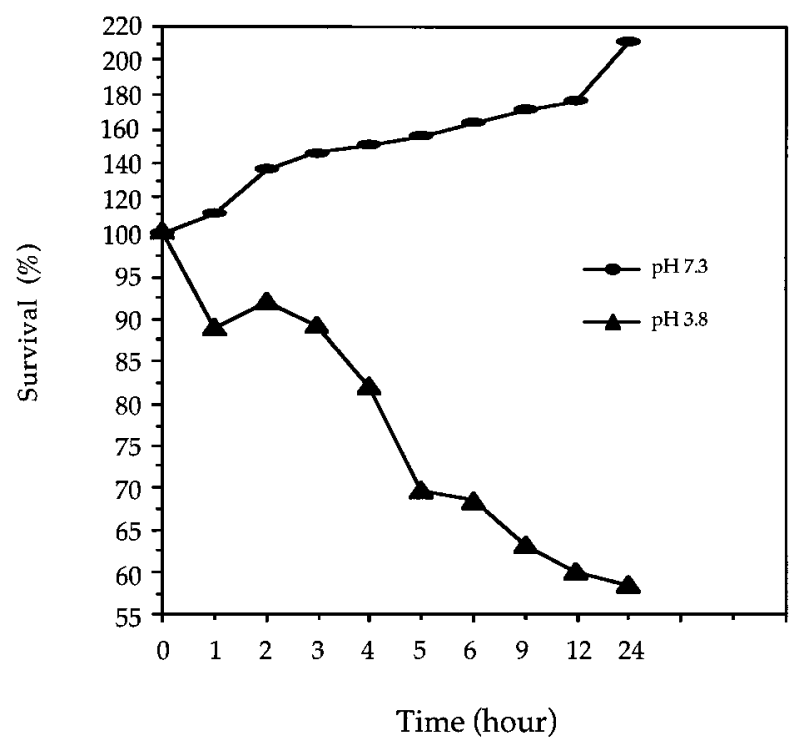

FIG. 4. Survival of B. abortus S2308 under reduced-pH conditions. Bacteria were grown and the $\mathrm{pH}$ was shifted as described in the text. Following the shift in $\mathrm{pH}$, the number of viable bacteria at each time point was determined by making serial dilutions in PBS and plating portions on TSA plates. Results for each time point are expressed as the average CFU per milliliter from three plates. Survival was determined in three separate experiments. Survival is determined as follows: number of CFU present at any given time/number of CFU present at $0 \mathrm{~h} \times 100 \%$. One hundred percent viability represents $8.75 \times 10^{8}$ cells per ml.

faces that function as specific receptors; several are important for phagocytosis and are often used by intracellular parasites as portals of entry into host cells (10). Bacterial pathogens are able to bind to the mammalian cell surface and promote endocytosis without stimulating intracellular activities which normally degrade or eliminate phagocytosed particles. Recent results suggest that the uptake of brucellae is probably mediated

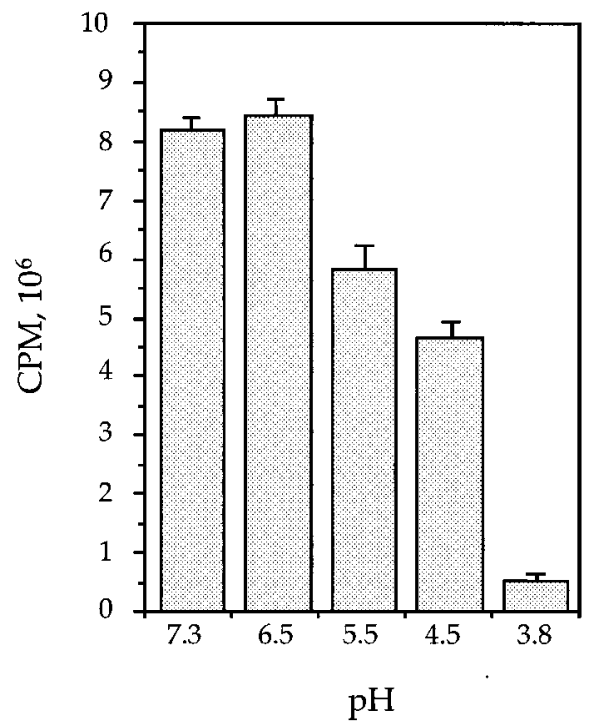

FIG. 5. Effect of $\mathrm{pH}$ on the incorporation of $\left[{ }^{35} \mathrm{~S}\right]$ methionine by $B$. abortus. $B$. abortus S2308 was grown to a density of approximately $10^{9} \mathrm{CFU} / \mathrm{ml}$ and the proteins were radiolabeled for $1 \mathrm{~h}$ at different $\mathrm{pHs}$ as described in the legend to Fig. 2. Values are the averages of $\left[{ }^{35} \mathrm{~S}\right]$ methionine incorporation in triplicate samples.

\section{$\begin{array}{llllllll}1 & 2 & 3 & 4 & 5 & 6 & 7 & 8\end{array}$}

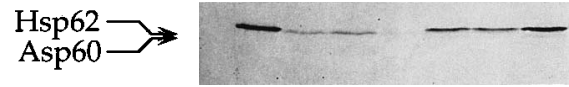

FIG. 6. Immunoprecipitation analysis of acid shock- and macrophage-induced Hsp62. Samples are as described for Fig. 1; all contained equal quantities of ${ }^{35}$ S-labeled proteins $\left(5 \times 10^{4} \mathrm{cpm}\right)$ and were immunoprecipitated with antiHsp62 and electrophoresed as described in Materials and Methods.

via multiple pathways, but the presence of one particular pathway may be important in ultimately determining susceptibility or resistance to brucellosis (10). In order to determine whether the in vitro assay represented a close approximation of the in vivo situation, we compared protein synthesis in brucellae exposed to macrophages with and without opsonizing antibody, complement, or both. The results shown in Fig. 8 (lanes 1 to 4 ) suggest that opsonization specifically increases the level of macrophage-induced proteins but is not required to induce

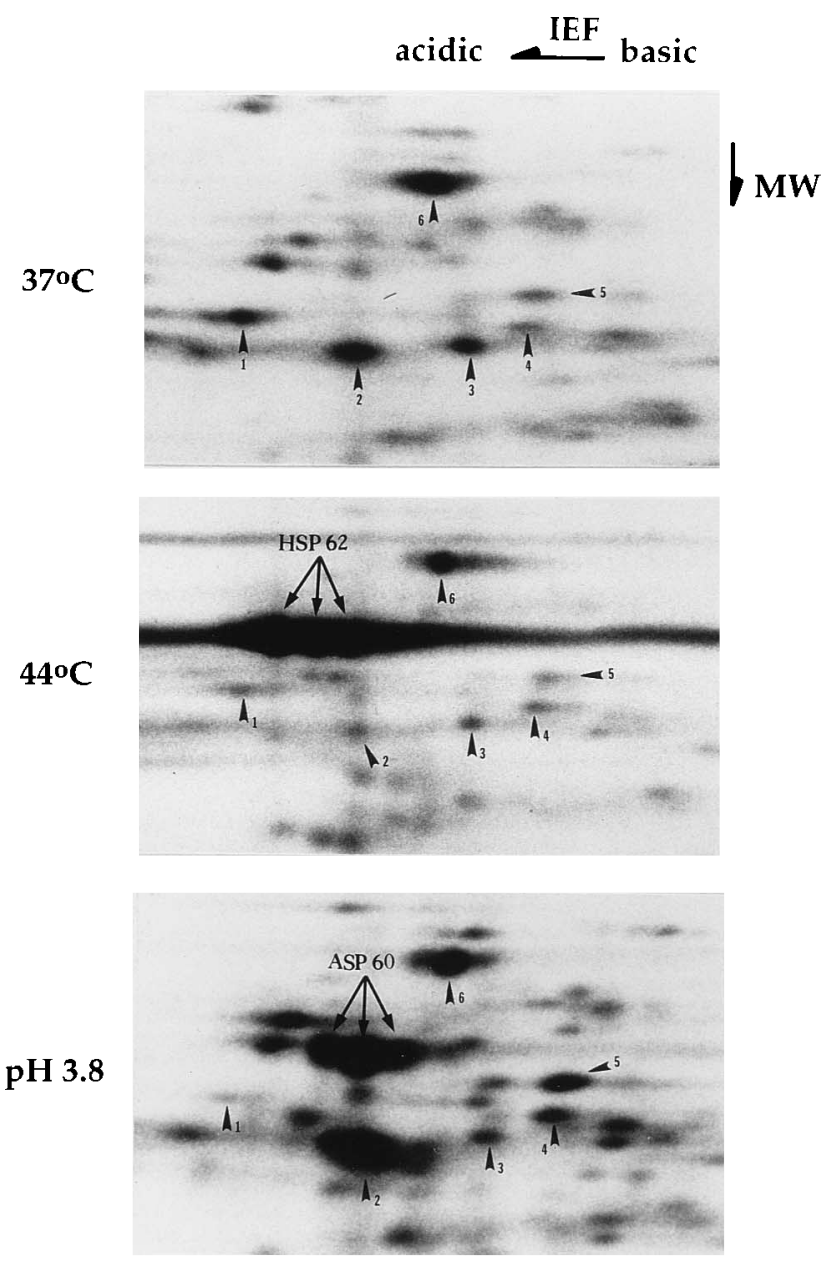

FIG. 7. Two-dimensional gel analysis of Hsp62 and Asp60. Two-dimensional gel electrophoresis was performed on ${ }^{35} \mathrm{~S}$-labeled proteins derived from B. abortus S2308 labeled under each of the three conditions described in Materials and Methods. The directions of IEF and SDS-PAGE are shown in the top right corner. Each of the numbered arrowheads represents a protein that is expressed under all three growth conditions. Hsp62 and Asp60 represent multiple protein spots with similar molecular weights but different isoelectric points. MW, molecular weight. 


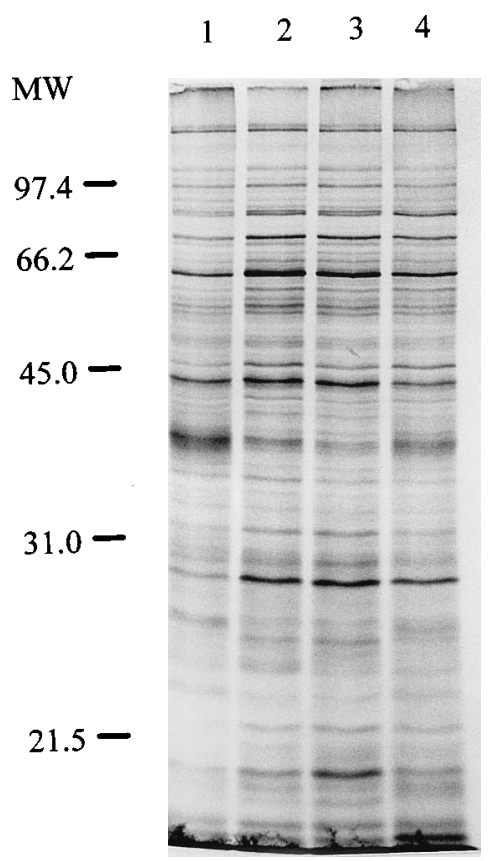

FIG. 8. Effect of opsonization on macrophage-induced protein synthesis. $B$. abortus S2308 was grown and proteins were radiolabeled within macrophages as described in Materials and Methods. Lane 1, nonopsonized organisms; lane 2, antibody-opsonized organisms; lane 3, complement-opsonized organisms; lane 4, antibody- and complement-opsonized organisms. MW, molecular weight (in thousands).

such synthesis. This may represent an adaptation to conditions as they exist within the infected host or an artifact of the use of the J774 cell line. Campbell et al. have suggested that opsonization has no detectable effect on the ultimate fate of Brucella spp. in bovine macrophages (10), and although the results shown here do not challenge that result, it may be argued that quantitative changes in gene expression are important for survival. Further experimentation along these lines will be performed with bovine macrophages.

\section{DISCUSSION}

The data presented in this work reveal the following: (i) synthesis of Brucella proteins is altered in response to acid stress, (ii) stress-induced protein synthesis is observed following phagocytosis by macrophages, and (iii) overlap between these and other Brucella stress responses exists. Stress conditions selected for this study mimic conditions to which Brucella spp. are naturally exposed and to which they have successfully adapted. Previous work has revealed that B. abortus exhibits a heat shock response which is similar to that of other prokaryotic organisms but is of extended duration (28). Little is known about the initial stages of Brucella infection (i.e., attachment and penetration of the epithelium and mucosa) (35). Although heat stress may accompany the initial ingestion of brucellae there does not appear to be an environmental source of infection, and the temperature of milk and aborted material is not expected to differ from the normal bovine core temperature. As such, heat stress does not appear to play a significant role in stimulating adaptive, host-specific expression.

Exposure to acidic environments occurs following ingestion by the host. Brucellae appear to be absorbed at the oral mucosa, and the phagosome or the phagolysosome of macrophages is presumably the first reduced-pH environment en- countered by the bacteria (19). Endosomal acidification in Vero cells has been shown to be necessary for B. abortus to transfer from the phagosome to the rough endoplasmic reticulum. This may be the mechanism by which Brucella replication occurs within the reproductive target tissue of the host species in the latter stages of infection (12). The ability of ingested $B$. abortus to resist acidic and inhospitable environments appears to be controlled by adaptive, host-specific expression.

The acid shock response in bacteria is characterized by adjustments in the activity and synthesis of proteins associated with many different processes, including (i) proton trafficking via proton pump, potassium/proton, and sodium/proton antiports (5); (ii) amino acid degradation via decarboxylases (4); and (iii) other uncharacterized changes in the synthesis of proteins $(15,21,22)$. Under in vitro conditions, organisms are sensitive to reduced acidity because of (i) ribosomes inactivated as a result of extended growth under acidic conditions (32); (ii) diminished cellular energy levels due to the active removal of excess $\mathrm{H}^{+}$by pumps required for long-term stabilization of internal pH (25); and (iii) altered outer membrane permeabilities due to increases in cell surface hydrophobicity (27). These changes could affect the uptake of solutes, decrease all biosynthetic activities, and result in a loss of $\mathrm{pH}$ homeostasis. Either the external or internal $\mathrm{pH}$ may be the signal for the acid shock response $(16,36,39)$, which may be modulated by at least three regulatory systems: RpoH (sigma 32) (21), KatF (sigma 38) (14, 40), and EnvZ/OmpR (20).

For B. abortus, acidification of the growth media results in the expression of several proteins not observed during heat stress (Fig. 1 and 2). The synthesis of Brucella proteins in response to acid stress is complex; proteins synthesized at $\mathrm{pHs}$ between 6.5 and 4.5 may be involved in a pre-acid shockinducible $\mathrm{pH}$ homeostasis, while the proteins expressed at $\mathrm{pH}$ 3.8 may be involved in an acid tolerance response as described for Salmonella spp. $(15,16)$. The synthesis of Asp24 increases as the $\mathrm{pH}$ of the medium decreases, while the synthesis of Asp60 may be observed only at pH 3.8. The synthesis of both proteins is optimal during the first $3 \mathrm{~h}$ following a $\mathrm{pH}$ shift from 7.3 to 3.8 and directly correlates with a period of elevated survival. Determination of the function of Asp24 must await identification of this gene product. Presumably, GroEL is involved in the folding, assembly, and transport of factors required for growth under these conditions, much as it functions in the assembly of the nitrogenase complex in Rhizobium meliloti (17) and in the assembly of urease-hemagglutinin complexes in Helicobacter pylori (13).

The phagocytic process is mediated by macrophage receptors which interact with the bacterial surface in a specific manner. A significant oxidative burst has been reported to occur when $B$. abortus is phagocytosed by macrophages following opsonization with heat-inactivated anti-Brucella serum (19). However, in contrast to Salmonella spp., the ability of macrophages to kill $B$. abortus is not associated with the production of oxidative reactants $(6,8)$. The observed increase in bacterial protein synthesis following opsonization may represent a protective response to increased oxidative conditions which occur as a result of exposure to opsonized $B$. abortus.

Although the synthesis of proteins changes under the in vivo and in vitro stress conditions examined, none of the stress responses appear to exactly resemble one another. The intracellular environment is presumably complex, and the stress response may not be a simple summation of the actions of various extracellular environmental stresses. Several heat shock proteins (Hsp62, Hsp70, and Hsp35) and acid shock proteins (Asp30 and Asp24), as well as some macrophage-specific pro- 
teins, are observed during the infection of macrophages. Presumably, synthesis of macrophage-induced proteins is the result of multiple regulons or a single regulon which partially overlaps the heat and acid shock regulons. Support for this comes from Salmonella experiments, which indicate that KatF, $\mathrm{PhoQ} / \mathrm{PhoP}$, and heat shock regulatory systems are involved in the activation of gene expression during the infection of macrophages $(3,7,14)$. Increased synthesis of Asp24 is consistent with exposure to the acidic intracellular environments. However, this expression did not match the level observed in vitro. This is consistent with the reported ability of Brucella spp. to inhibit phagosome-lysosome fusion $(19,23)$.

The presumptive relationship between Asp60 and Hsp62 will require further definition. Modified forms of GroEL appear in Escherichia coli during the heat shock response and, following prolonged storage, exhibit retarded migration in SDS-PAGE and an increasingly acidic isoelectric point on twodimensional gels $(29,41)$. Preliminary Southern blot analysis (data not shown) has ruled out the possibility that Asp60 represents the product of a related gene, as observed for Mycobacterium spp., streptomycetes, and Synechocystis spp. (18, 24, 26, 38).

The methods used to identify the Brucella stress-induced proteins reveal overall changes which occur in Brucella spp. following exposure to environmental stress. A more detailed analysis of each stress protein along with coordinated genetic studies will be required to fully understand the regulation of gene expression as it pertains to the stress response.

\section{ACKNOWLEDGMENTS}

This work was supported in part by grants from the U.S. Department of Agriculture (92-37204-8002) and the Texas Advanced Technology Research Program (AG001).

\section{REFERENCES}

1. Abu Kwaik, Y., B. I. Eisenstein, and N. C. Engleberg. 1993. Phenotypic modulation by Legionella pneumophila upon infection of macrophages. Infect. Immun. 61:1320-1329.

2. Alton, G. G., L. M. Jones, and D. E. Pietz. 1975. Laboratory techniques in brucellosis. World Health Organization, Geneva.

3. Aranda, C. M. A., J. A. Swanson, W. P. Loomis, and S. I. Miller. 1992. Salmonella typhimurium activates virulence gene transcription within acidified macrophage phagosomes. Proc. Natl. Acad. Sci. USA 89:10079-10083.

4. Auger, E. A., K. E. Redding, T. Plumb, L. C. Childs, S.-Y. Meng, and G. N. Bennett. 1989. Construction of lac fusions to the inducible arginine and lysine decarboxylase genes of Escherichia coli K-12. Mol. Microbiol. 3:609620

5. Booth, I. R. 1985. Regulation of cytoplasmic pH in bacteria. Microbiol. Rev. 49:359-378.

6. Bounous, D. I., F. M. Enright, K. A. Gossett, and C. M. Berry. 1993. Phagocytosis, killing, and oxidant production by bovine monocyte-derived macrophages upon exposure to Brucella abortus strain 2308. Vet. Immunol. Immunopathol. 37:243-256.

7. Buchmeier, N. A., and F. Heffron. 1990. Induction of Salmonella stress proteins upon infection of macrophages. Science 248:730-732.

8. Buchmeier, N. A., C. J. Lipps, M. Y. H. So, and F. Heffron. 1993. Recombination-deficient mutants of Salmonella typhimurium are avirulent and sensitive to the oxidative burst of macrophages. Mol. Microbiol. 7:933-936.

9. Campbell, G. A., and L. G. Adams. 1992. The long-term culture of bovine monocyte-derived macrophages and their use in the study of intracellular proliferation of Brucella abortus. Vet. Immunol. Immunopathol. 34:291-305.

10. Campbell, G. A., L. G. Adams, and B. A. Sowa. 1994. Mechanisms of binding of Brucella abortus to mononuclear phagocytes from cows naturally resistant or susceptible to brucellosis. Vet. Immunol. Immunopathol. 41:295-306.

11. Carazo, J. M., S. Marco, G. Abella, J. L. Carrascosa, J.-P. Secilla, and M. Muyal. 1991. Electron microscopy study of GroEL chaperonin: different views of the aggregate appear as a function of cell growth temperature. J. Struct. Biol. 106:211-220.

12. Detilleux, P. G., B. L. Deyoe, and N. F. Cheville. 1991. Effect of endocytic and metabolic inhibitors on the internalization and intracellular growth of $\mathrm{Bru}$ cella abortus in Vero cells. Am. J. Vet. Res. 52:1658-1664.

13. Evans, D. J., Jr., D. G. Evans, L. Engstrand, and D. Y. Graham. 1992.
Urease-associated heat shock protein of Helicobacter pylori. Infect. Immun. 60:2125-2127.

14. Fang, F. C., S. J. Libby, N. A. Buchmeier, P. C. Loewen, J. Switala, J. Harwood, and D. G. Guiney. 1992. The alternative $\sigma$ factor KatF (RpoS) regulates Salmonella virulence. Proc. Natl. Acad. Sci. USA 89:11978-11982.

15. Foster, J. W. 1991. Salmonella acid shock proteins are required for the adaptive acid tolerance response. J. Bacteriol. 173:6896-6902.

16. Foster, J. W. 1993. The acid tolerance response of Salmonella typhimurium involves transient synthesis of key acid shock proteins. J. Bacteriol. 175: 1981-1987.

17. Govezensky, D., T. Greener, G. Segal, and A. Zamir. 1991. Involvement of GroEL in nif gene regulation and nitrogenase assembly. J. Bacteriol. 173: 6339-6346.

18. Guglielmi, G., P. Mazodier, C. J. Thompson, and J. Davies. 1991. A survey of the heat shock response in four Streptomyces species reveals two groELlike genes and three GroEL-like proteins in Streptomyces albus. J. Bacteriol. 173:7374-7381.

19. Harmon, B. G., L. G. Adams, and M. Frey. 1988. Survival of rough and smooth strains of Brucella abortus in bovine mammary gland macrophages. Am. J. Vet. Res. 49:1092-1097.

20. Heyde, M., and R. Portalier. 1987. Regulation of major outer membrane porin proteins of Escherichia coli K12 by pH. Mol. Gen. Genet. 208:511-517.

21. Heyde, M., and R. Portalier. 1990. Acid shock proteins of Escherichia coli. FEMS Microbiol. Lett. 69:19-26.

22. Hickey, E. W., and I. N. Hirshfield. 1990. Low-pH-induced effects on patterns of protein synthesis and on internal $\mathrm{pH}$ in Escherichia coli and Salmonella typhimurium. Appl. Environ. Microbiol. 56:1038-1045.

23. Jiang, X., and C. L. Baldwin. 1993. Effects of cytokines on intracellular growth of Brucella abortus. Infect. Immun. 61:124-134.

24. Kong, T. H., A. R. M. Coates, P. D. Butcher, C. J. Hickman, and T. M. Shinnick. 1993. Mycobacterium tuberculosis expresses two chaperonin-60 homologues. Proc. Natl. Acad. Sci. USA 90:2608-2612.

25. Kugel, H., A. Mayer, G. O. Kirst, and D. Leibfritz. 1990. The energy requirements of $\mathrm{pH}$ homeostasis define the limits of $\mathrm{pH}$ regulation-a model. Biochim. Biophys. Acta 1054:33-40.

26. Lehel, C., D. Los, H. Wada, J. Gyorgyei, I. Horvath, E. Kovacs, N. Murata, and L. Vigh. 1993. A second groEL-like gene, organized in a groESL operon is present in the genome of Synechocystis sp. PCC 6803. J. Biol. Chem. 268:1799-1804.

27. Leyer, G. J., and E. A. Johnson. 1993. Acid adaptation induces cross-protection against environmental stresses in Salmonella typhimurium. Appl. Environ. Microbiol. 59:1842-1847.

28. Lin, J., L. G. Adams, and T. A. Ficht. 1992. Characterization of the heat shock response in Brucella abortus and isolation of the genes encoding the GroE heat shock proteins. Infect. Immun. 60:2425-2431.

29. Marco, S., J. M. Valpuesta, G. Rivas, G. Andres, C. S. Martin, and J. L. Carrascosa. 1993. A structural model for the GroEL chaperonin. FEMS Microbiol. Lett. 106:301-308.

30. Miller, J. F., J. J. Mekalanos, and S. Falkow. 1989. Coordinate regulation and sensory transduction in the control of bacterial virulence. Science 243: 916-922.

31. Miller, S. I. 1991. PhoP/PhoQ: macrophage-specific modulators of Salmonella virulence? Mol. Microbiol. 5:2073-2078.

32. Nauman, R. K., D. J. Silverman, and H. Voelz. 1971. Ribosomal helices: formation in Escherichia coli during acidic growth. J. Bacteriol. 107:358-360.

33. Nicoletti, P. 1980. The epidemiology of bovine brucellosis. Adv. Vet. Sci. Comp. Med. 24:69-98.

34. O'Farrell, P. H. 1975. High-resolution two-dimensional electrophoresis of proteins. J. Biol. Chem. 250:4007-4021.

35. Payne, J. M. 1959. The pathogenesis of experimental brucellosis in the pregnant cow. J. Pathol. Bacteriol. 78:447-463.

36. Raja, N., M. Goodson, W. C. M. Chui, D. G. Smith, and R. J. Rowbury. 1991. Habituation to acid in Escherichia coli: conditions for habituation and its effects on plasmid transfer. J. Appl. Bacteriol. 70:59-65.

37. Riley, L. K., and D. C. Robertson. 1984. Ingestion and intracellular survival of Brucella abortus in human and bovine polymorphonuclear leukocytes. Infect. Immun. 46:224-230.

38. Rinke de Wit, T. F., S. Bekelie, A. Osland, T. L. Miko, P. W. Hermans, D. van Soolingen, T. W. Drijfhout, R. Schoningh, A. A. Janson, and J. E. Thole. 1992. Mycobacteria contain two groEL genes: the second Mycobacterium leprae groEL gene is arranged in an operon with groES. Mol. Microbiol. 6:1995-2007.

39. Rowbury, R. J., M. Goodson, and A. D. Wallace. 1992. The PhoE porin and transmission of the chemical stimulus for induction of acid resistance (acid habituation) in Escherichia coli. J. Appl. Bacteriol. 72:233-243.

40. Schellhorn, H. E., and V. L. Stones. 1992. Regulation of katF and katE in Escherichia coli K-12 by weak acids. J. Bacteriol. 174:4769-4776.

41. Sherman, M. Y., and A. L. Goldberg. 1992. Heat shock in Escherichia coli alters the protein-binding properties of the chaperonin GroEL by inducing its phosphorylation. Nature (London) 357:167-169. 